\title{
Hydrology Properties at Sembrong Dam Reservoir in Johor
}

\author{
Halizah Awang ${ }^{1,}$, Zawawi Daud ${ }^{2, b}$, Tan Lai Wai ${ }^{2, c}$ \\ and Mohd Zainuri Mohd Hatta ${ }^{2, \mathrm{~d}}$ \\ ${ }^{1}$ Faculty of Technical and Vocational Education, Universiti Tun Hussein Onn Malaysia, 86400 Parit \\ Raja, Batu Pahat, Johor Malaysia \\ ${ }^{2}$ Faculty of Civil and Environmental Engineering, Universiti Tun Hussein Onn Malaysia, 86400 Parit \\ Raja, Batu Pahat, Johor Malaysia \\ ahalizah@uthm.edu.my, 'bawawi@uthm.edu.my, laiwai@uthm.edu.my, dmzainuri88@gmail.com
}

Keywords: Sembrong dam, water catchment, rainfall, soil and evaporation.

Dam reservoir required a proper management that all components of the water resource system be known. This study focused on soil condition, rainfall and evaporation by Sembrong dam in Johor. The available data from soil loss estimation by environment impact assessment (EIA) and average of year from 1984 to 2009 daily rainfall and evaporation data across the Sembrong dam catchment by the Water Resources Management and Hydrology Division, Department Of Irrigation and Drainage, Malaysia. Result indicated that soil loss about $487.12 \mathrm{~kg} / \mathrm{km}^{2} / \mathrm{day}$, for rainfall and evaporation records are $1862 \mathrm{~mm}$ and $1098 \mathrm{~mm}$. This result effect on the water quality of water in Sembrong dam reservoir in Johor by those hydrology charateristics..

\section{Introduction}

Water is fresh potable water where is not always available at the right time or the right place for human or ecosystem use [1]. Water impoundments constructed by damming rivers are called dam reservoirs. Under the Malaysian Western Johore Agricultural Development Project, the main function of the Sembrong dam is flood mitigation. The secondary function of the dam was to provide a clean water supply to 240,000 consumers in Kluang district area where used for daily activities [2]. Water from the Sembrong dam reservoir is treated at the West Sembrong Water Treatment Plant before the distribution. Daily reservoir inflow data were extracted by applying the water balance model to the Sembrong dam reservoir. Developing hydrologic hazard curves for risk assessment uses the length of record and type of data to determine the extrapolation limits for flood frequency analysis [3]. Extrapolation beyond the data is often necessary to provide information needed for dam safety risk assessments [4]. The sources of information used for flood hazard analyses include stream flow, precipitation records and flood data.

\section{Methodology}

\section{Study Area and Sampling Methods}

Sampling stations were selected based on criteria of utilization of water and effect nearby activities. Sembrong Lake was located in the districts of Air Hitam and Kluang, within the range of $2^{\circ} 01^{\prime} 35^{\prime \prime} \mathrm{N}-1^{\circ} 58^{\prime} 29^{\prime \prime} \mathrm{N}$ latitude and $103^{\circ} 09^{\prime} 32^{\prime \prime} \mathrm{E}-103^{\circ} 12^{\prime} 57^{\prime \prime} \mathrm{E}$ longitude (Figure 1). 


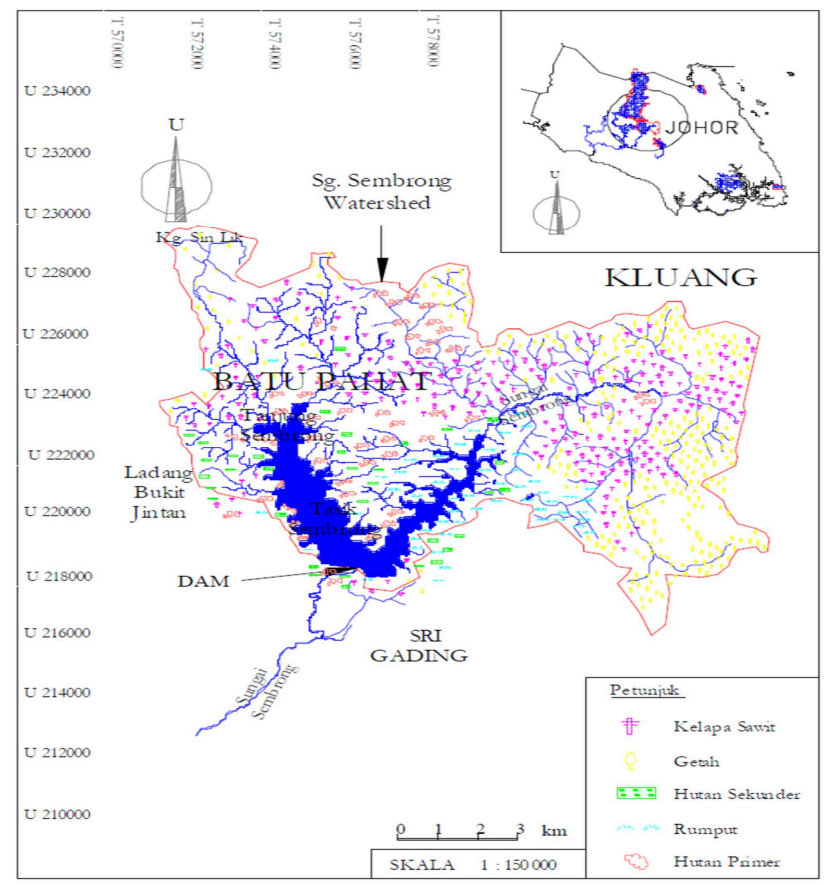

Figure 1. Sembrong dam reservoir $130 \mathrm{~km}^{2}$ catchment area.

The rainfall data were sourced from the Environment Impact Assessment (EIA) and the Department of Irrigation and Drainage, which was in charge of the reservoir operations whilst reservoir inflow data were extracted using water balance equation for the reservoir in Tabe 1.

Table 1. Sembrong dam reservoir rainfall and evaporation station

\begin{tabular}{|l|l|l|}
\hline Station no. and name & Type of data & Period of data obtained \\
\hline 1931003 & Rainfall & October 1982 to \\
Empangan Sg. Sembrong, & & December 2009 \\
Air Hitam, Johor & & \\
\hline 2033301 & & October 1982 to \\
Stor JPS, Kluang, Johor & Evaporation & December 2009 \\
\hline
\end{tabular}

\section{Results and discussions}

\section{Soil characteristics}

Sembrong dam is provided with two flood regulating structures to control floods with maximum outflow of $42 \mathrm{~m}^{3} / \mathrm{s}$. The normal water level of the reservoir is maintained at $9.0 \mathrm{~m}$ by maximum operating depth (M.O.D.) to meet the water supply demand. Outlet for the water supply is provided in the upstream guide wall of the flood-regulating outlet. A maximum of $1.0 \mathrm{~m}^{3} / \mathrm{s}$ of water can be drawn off through an $800 \mathrm{~mm}$ diameter pipe at the invert level of $2.870 \mathrm{~m}$ M.O.D. for water supply where this effect by the soil loss in $\mathrm{dm}$. The compensation water draw-off is $1.2 \mathrm{~m}^{3} / \mathrm{s}$ through a $900 \mathrm{~mm}$ pipe, built into the flood regulating outlet structure. The compensation draw-off is required to maintain water quality and to keep the river downstream in a viable condition [5].

Figure 2 shows the water depths at 12 cross-sections of the Sembrong dam reservoir. The intervals of each cross-section are ranged between $500 \mathrm{~m}$ (along Sembrong River) to $1500 \mathrm{~m}$ (along Merpo River) intervals. Measurements of the water depths were made on $9^{\text {th }}$ of November 2010 to $10^{\text {th }}$ November 2010. The water levels in the reservoir are $9.0 \mathrm{~m}$ M.O.D. during both days. The 
reservoir bed slopes towards the dam outlet where it gives a depth with the maximum water depth recorded is $4.52 \mathrm{~m}$, upstream of the dam.

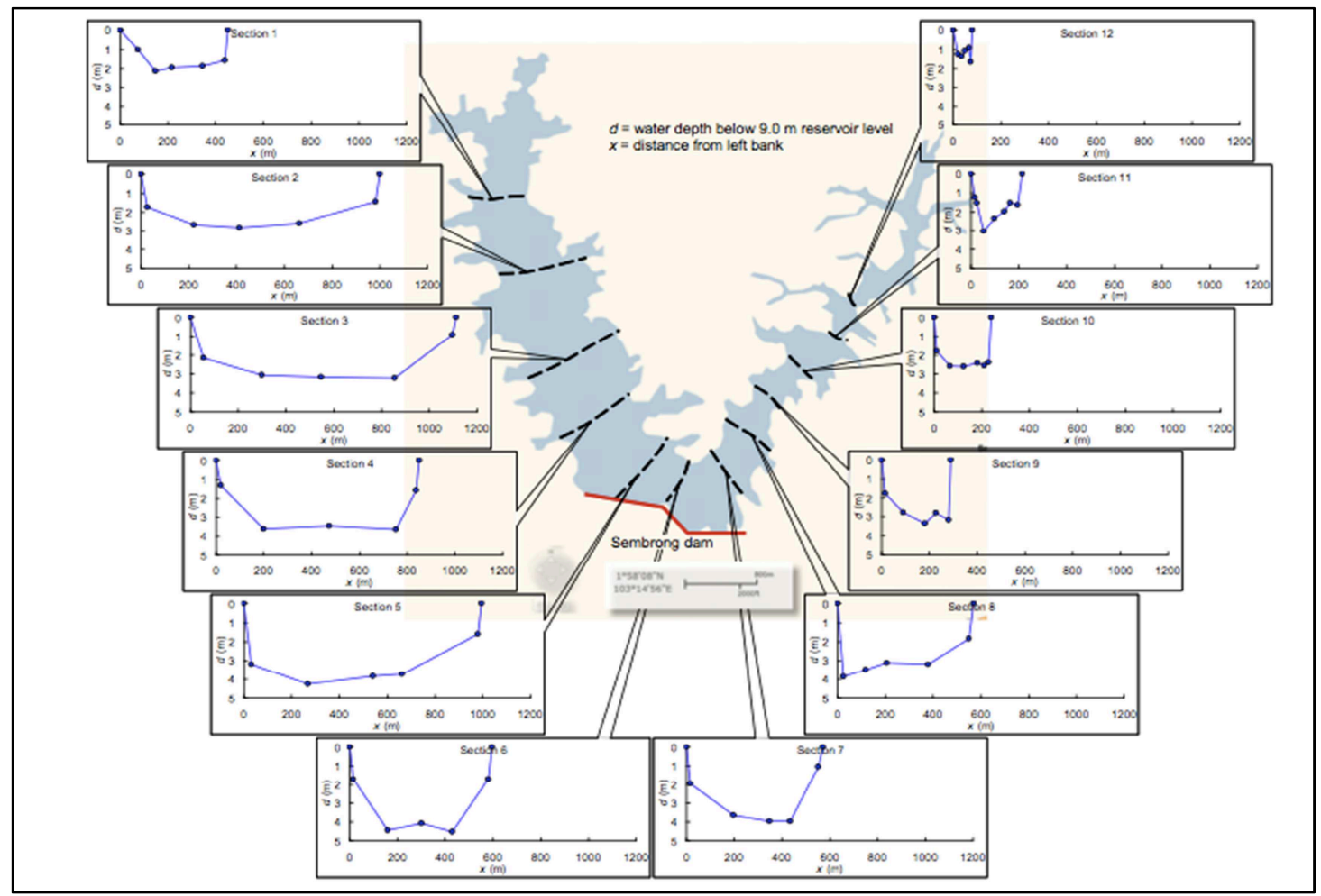

Figure 2. Water depth across Sembrong dam reservoir at 12 measuring cross-section.

According to the Environment Impact Assessment (EIA) report produced for the Modern Agriculture Project, Kluang, the soil loss was estimated at a rate of $487 \mathrm{~kg} / \mathrm{km}^{2} /$ day (equivalent to 1.8 tons/ha/year) with an extreme rate of $48712 \mathrm{~kg} / \mathrm{km}^{2} /$ day for bare soil. In terms of sedimentation into Sembrong dam reservoir, the estimated generated sediments were approximately 130 $\mathrm{kg} / \mathrm{km}^{2} /$ day (equivalent to 0.19 ton/ac/year) with an extreme rate of $12998 \mathrm{~kg} / \mathrm{km} 2 /$ day if the soil was bared. Sembrong dam reservoir was affected by the modern agriculture project like new farm for agriculture plant besides the dam, which is total of 5.6\% from the catchment area [6].

\section{Rainfall and evaporation pattern}

The available rainfall and evaporation records, the average annual total rainfall and evaporation recorded at Sembrong dam rainfall station are $1862 \mathrm{~mm}$ and $1098 \mathrm{~mm}$, respectively. The rainfall and evaporation records reported in this report are obtained in this study. Generally, heavy rainfall occurs during the months of October to January and again in March and April due to the climate changes of the monsoons by Figure 4. From Figure 3, evaporation rate is quite uniform. The study made by Ministry of Agriculture between years 1964 to 1974, the mean annual evaporation for Sembrong dam reservoir catchment is $1800 \mathrm{~mm} /$ year from Figure 5 [7].

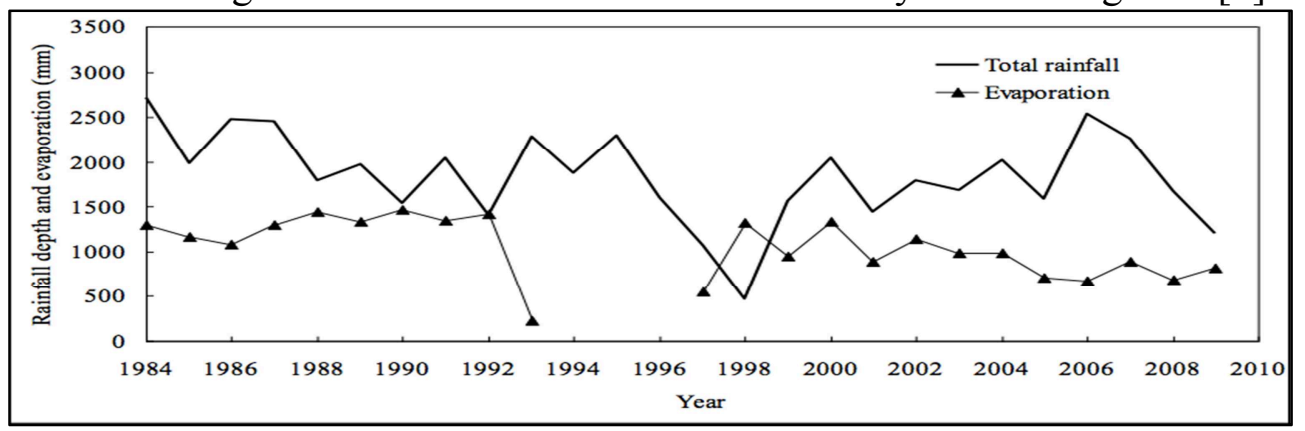

Figure 3. Annual rainfall depth and evaporation depth between years 1984 to 2009. 


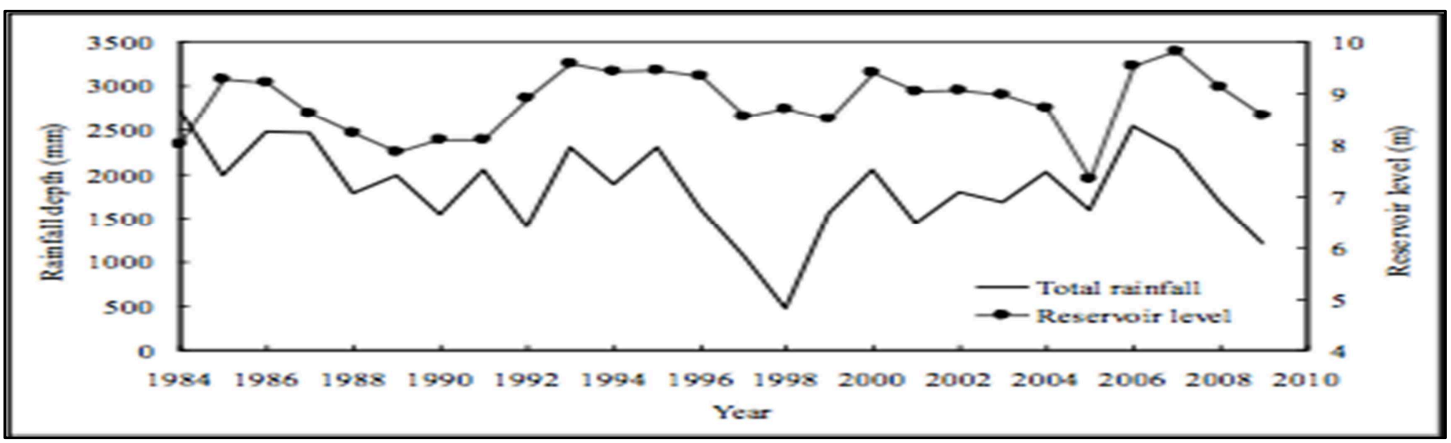

Figure 4. Annual rainfall depth and Sembrong reservoir level from year 1984 to 2009.

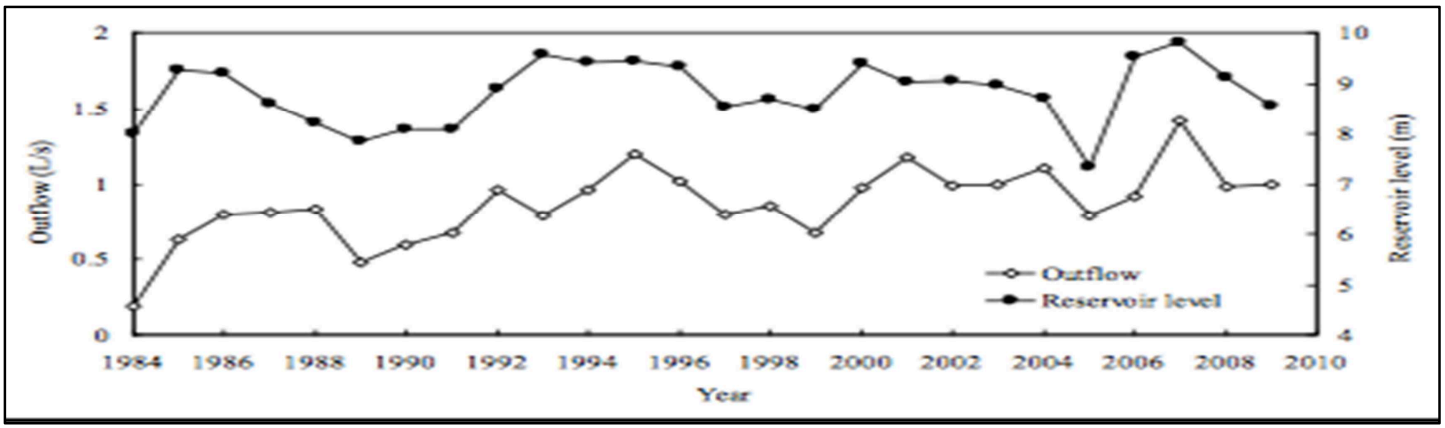

Figure 5. Annual outflow and Sembrong reservoir level from year 1984 to 2009.

\section{Theoretical filling time}

This theoretical from Table 2 value shows the average recurrence interval of flood event [8].

Table 2. Theoretical filling time.

\begin{tabular}{|c|c|c|}
\hline 10-year ARI flood event & 100-year ARI flood event & Maximum flood event \\
\hline $\begin{array}{l}\text { Infilling rate }= \\
\quad \text { Volume flake }\left(\mathrm{m}^{3}\right)\end{array}$ & $\begin{array}{l}\text { Infilling rate }= \\
\quad \text { Volume flake }\left(\mathrm{m}^{3}\right)\end{array}$ & $\begin{array}{l}\text { Infilling rate }= \\
\quad \text { Volume flake }\left(\mathrm{m}^{3}\right)\end{array}$ \\
\hline $\begin{array}{c}\text { Inflow rate }\left(\mathrm{m}^{3} \text { day }^{-1}\right) \\
=23.59 \text { days }\end{array}$ & $\begin{array}{c}\text { Inflow rate }\left(\mathrm{m}^{3} \text { day }^{-1}\right) \\
=1.72 \text { days }\end{array}$ & $\begin{array}{c}\text { Inflow rate }\left(\mathrm{m}^{3} \text { day }^{-1}\right) \\
=1.24 \text { days }\end{array}$ \\
\hline
\end{tabular}

*ARI: The long-term average number of years between the occurrences of a flood.

\section{Theoretical retention time}

Retention time is also known as water residence time, hydraulic detention time, and retention rate or flushing rate [9]. Retention time should be calculated for each year or each appropriate shorter time period should the actual reservoir volume vary substantially during the considered period. The retention time of Sembrong dam reservoir during normal storage with water level at 8.5 M.O.D.

\section{Conclusions}

As conclusion, it can be conclude that Sembrong River Dam slightly shows high soil loss where is consist of soft fine grained silty clay material with organic matter, tree roots and decaying timber. For rainfall and evaporation records are $1862 \mathrm{~mm}$ and $1098 \mathrm{~mm}$. This study shows high rainfall and evaporation between years that had been study. This study also would relate to the development of water quality on Sembrong dam reservoir.

\section{Acknowledgments}

This research was supported by MOHE and UTHM for financial support. 


\section{References}

[1] F.K. Fang, W. Easter and P.L. Brezonik: Journal of the American Water Resources Association Vol. 41(2005), p. 645-5

[2] M. Traskraba and J.G. Tundisi: Reservoir Water Quality Management, UNEP/ILEC Guidelines of Lake Management Series 9(1999).

[3] R. Aggarwal, and S. Arora: International Journal Of Scientific \& Technology Research Vol. 1(2012), p. 52-68.

[4] S.H. Elizabeth, B. Casey, M. Kevin, W.C. Bradley, D.J. Scott: Journal of Hydrology Vol. 503(2013), p. 196-208

[5] W.A. Amneera, N.W.A. Z. Najib, S.R. M. Yusof, S.Ragunathan: International Journal of Civil \& Environmental Engineering Vol. 13 (2013) p. 1-6.

[6] Ministry of Agriculture and Agro-based Industry Malaysia: Kajian Penilaian Awal $\square$ Kesan Alam Sekitar (EIA) Projek Pertanian Moden di atas Lot PTD 24651-24655, 14209, 14212, 14213, Lot 8211-8216, 5500, 5569, 5671, 5672, 5844, 9098-9101, 9135-9137 Mukim Sri Gading, Daerah Batu Pahat dan Lot 5502, 5503, 2296, 2297, PTD 14745 Mukim Kluang, Daerah Kluang, Johor Darul Ta'zim (2003).

[7] D. Said, K. Stevens and G. Sehlke. Environmental assessment: $\square$ Environmental Management Vol. 34 (2004), p. 406-414.

[8] T. Davie: Fundamentals of Hydrology. London: Routledge Fundamentals Of Physical Geograhy. (2003), ISBN 0-203-93366-4.

[9] P.D. Caroline and T. Wardah: International Journal of Civil \& Environmental Engineering Vol. 12(2006), p. 71-75 